\title{
PENGARUH PELAKSANAAN MUZARA'AH TERHADAP KESEJAHTERAAN PETANI DI KECAMATAN LHOKSUKON KABUPATEN ACEH UTARA
}

\author{
Siti Nujul Fajri ${ }^{\text {a }}$, Yulius Dharma ${ }^{\text {a2 }}$ \\ ${ }^{a}$ Fakultas Ekonomi dan Bisnis Universitas Malikussaleh \\ 1 Corresponding author : Srinujul@gmail.com \\ 2 yuliusdharma@unimal.ac.id
}

A R T I C L E I N F O R M A T I O N
Keywords:
Muzara'ah, Tingkat Kesejateraan
Petani

\section{A B S T RA C T}

This study aims to analyze the Effect of Muzara'ah on Farmers' Welfare Levels in Lhoksukon District, North Aceh Regency. The study uses simple linear regression analysis. The data collects from 67 respondents. The results of the study Partially partially found that muzara'ah had a positive and significant effect on the welfare of farmers in Lhoksukon District, North Aceh Regency.

\section{PENDAHULUAN}

Tidak sedikit masyarakat pedesaan yang mempunyai keahlian dibidang pertanian tetapi tidak mempunyai lahan atau tempat usaha tani dikerjakan dan tidak sedikit pula orang yang memiliki lahan pertanian tetapi tidak mempunyai keahlian untuk mengolahnya bahkan tidak mampu untuk mengolahnya karena terlalu banyak lahan pertanian yang dimiliki. Islam memberikan solusi dengan adanya konsep muzara'ah seperti yang telah dipraktekan oleh Rasulullah SAW dan para sahabat sebelumnya, pengertian konsep muzara'ah secara umum yaitu kerjasama yang dilakukan oleh kedua belah pihak (pemilik lahan dan penggarap yang mempunyai keahlian/petani) dengan perjanjian bagi hasil yang jumlahnya menurut kesepakatan bersama. Konsep muzara'ah ini akan memberikan dampak terhadap pertumbuhan perekonomian masyarakat pedesaan

Kesejahteraan petani di Kabupaaten Aceh Utara pada Tahun 2018 mengalami pergeseran yang negatif hal ini terlihat dari banyaknya keluhan petani terhadap adanya penurunan sejumlah produksi padi yang di sebabkan terjadinya banjir pasca panen serta adanya hama khusus pada tanaman padi. Kesejahteraan petani yang semakin rendah juga di rasakan oleh sejumlah petani yang bekerja hanya sebagai pengelola lahan sawah.

Petani yang sejahtera merupakan masyarakat yang mampu menggunakan sumber pendapatan untuk memenuhi kebutuhan seharihari. Tingkat kesejahteraan masyarakat bisa diukur dari tingkat pemenuhan kebutuhan keluarga yang meliputi kebutuhan pangan dan non pangan kesejahteraan yang dimaksud adalah terpenuhinya kebutuhan dasar.

Untuk mencapai tingkat kesesjahteraan para petani tentunya membutuhkan sejumlah lahan yang luas serta berbagai sarana pendukung dalam mengelola lahan sawah. Mayoritas masyarakat pedesaan yang hanya mengandalkan dan menggantungkan biaya hidupnya dari hasil pertanian, di mana taraf kesejahteraan mereka berbeda-beda. Sebagian dari mereka ada yang memiliki lahan sendiri untuk digarap, yang luasnya bervariasi. Tapi ada juga yang tidak memiliki lahan sendiri untuk digarap sehingga untuk mencukupi kebutuhan mereka bekerjasama dengan yang memiliki lahan untuk menggarap lahan pertaniannya dengan imbalan bagi hasil. Kebanyakan dari mereka itu telah memiliki lahan sendiri tapi karena hasilnya belum mencukupi, mereka juga bekerja di lahan milik orang lain dengan imbalan bagi hasil pertanian. Ada juga 
orang yang memiliki lahan pertanian tetapi tidak mempunyai keahlian dalam bertani, atau dikarenakan sudah lanjut usia sehingga penggarapannya diwakili orang lain dengan mendapat sebagian hasilnya. Kondisi seperti ini pada umumnya terlihat pada masyarakat pedesaan kita saat ini, wajar kiranya sistem pengolahan lahan pertanian dengan bagi hasil (muzara'ah) ini berkembang di masyarakat pedesaan pada umumnya. Karena pada dasarnya manusia tidak ada yang sama, kepribadian dan kemampuan masing-masing berbeda serta memiliki berbagai keinginan.

Oleh karena itu perlu dibangun suatu masyarakat yang maju dan makmur agar rasa saling percaya dan kerjasama dapat tumbuh di kalangan masyarakat. Dalam masyarakat, setiap orang mempunyai ketergantungan dengan orang lain untuk memenuhi kebutuhannya. Seringkali seseorang memiliki kemauan untuk mengolahnya. Hal yang sama dapat dikatakan mengenai pengalihan kekayaan yaitu misalnya seseorang mempunyai cukup waktu untuk berdagang (bisnis lain) atau tidak mempunyai kemampuan dan kekuatan untuk memikul beban dan kesukaran perdagangan (atau bisnis lainnya), atau terikat dengan pekerjaan yang lebih tinggi dan tidak dapat mengolah tanah sendiri. Oleh karena itu dibutuhkan saling tolong menolong agar dengan pemberian kekayaan yang dimiliki (modal atau tanah) kepada orang lain dapat membagi keuntungan dengan mereka.

Sistem ini menjadi suatu yang penting ketika ada orang-orang yang memiliki keahlian tapi tidak memiliki lahan dan sementara yang lain memiliki lahan tanpa modal dan tenaga kerja. Berdasarkan keadaan seperti ini dengan saling bantu-membantu dan kerjasama maka sistem bagi hasil merupakan cara efektif untuk menghasilkan lebih banyak tanah yang diolah sehingga menguntungkan kedua belah pihak. Bagi mereka yang tidak memiliki lahan tapi memiliki kemampuan, sistem ini akan membukakan mereka peluang pekerjaan yang selanjutnya dapat meningkatkan pendapatan yang membawa dampak pada kesejahteraan kedua belah pihak. Disamping juga akan terjalinnya rasa persaudaraan yang lebih erat karena masingmasing pihak merasa saling membutuhkan.
Seorang pemilik lahan mungkin saja tidak memiliki waktu untuk mengolah lahannya karena disibukkan oleh hal-hal yang lain, sedang di sisi lain, seorang petani membutuhkan lahan yang bisa digarap dan ia tidak memiliki lahan tersebut. Sistem muzara'ah ini sangat membantu mereka yang memiliki lahan tapi tidak mempunyai waktu untuk menggarapnya dan mereka yang tidak memiliki lahan tapi memiliki keahlian dalam bertani. Sistem muzâra'ah ini sebenarnya sudah dikenal dan dipraktekkan di kalangan masyarakat khususnya di Indonesia, yang mungkin dengan berbagai macam istilah dan penamaan. Penerapan sistem ini pada umumnya dapat dilihat pada masyarakat pedesaan yang hidupnya mengandalkan pertanian. Karena sistem ini akan membentuk kerjasama antara pemilik lahan dan petani penggarap yang didasari rasa persaudaraan antara kedua belah pihak. Dan juga sangat membantu mereka yang memiliki lahan tapi tidak mempunyai waktu untuk menggarapnya dan mereka yang tidak memiliki lahan tapi memiliki keahlian dalam bertani.

Menurut Al-syafi'i (2001), muzara'ah adalah seorang pekerja menyewa tanah dengan apa yang dihasikan dari tanah tersebut. Lahan persawahan yang dimiliki oleh setiap muzara'ah sangat bermanfaat untuk mensejahterakan petani dilihat dari sumber penghasilan utama dari 75 desa adalah bertani dengan jumlah petaninya mencapai 6.885 .

Pelaksanaan akad muzara'ah dijalankan sesuai dengan perjanjian yang di sepakati antara pemilik lahan dengan pengelola lahan. Sebagian besar pengelola lahan yang melakukan sewa kepada pemilik tanah tidak memberikan hasil produksi kepada pemilik tanah pada saat panen, Akan tetapi apabila pengelola lahan hanya mengelola lahannya dan sejumlah biaya di tanggung oleh pemilik lahan maka hasil produksi pada akhir periode akan di bagikan sesuai dengan perjanjian.

Kecamatan Lhoksukon terdapat 75 Desa yang memiliki luas lahan masing-masing. Dari jumlah tersebut 5 desa yang dipilih yang menjadi lokasi yaitu yang memiliki luas lahan sawah dan terdapat pengelola akad muzaraah. Adapun luas lahan yang digunakan yaitu sebagai berikut : 
Tabel 1

Jumlah Data Jumlah Lahan Di Kecamatan Lhoksukon

\begin{tabular}{|c|l|c|}
\hline No. & \multicolumn{1}{|c|}{ Nama Desa } & Luas Desa (Ha) \\
\hline 1. & Mns Arongan & 273 \\
2. & Trieng Matang Ubi & 328 \\
3. & Bintang Hu & 694 \\
4. & Reudeup & 562 \\
5. & Nga Matang Ubi & 337 \\
\hline \multicolumn{2}{|c|}{ Jumlah } & 2194 \\
\hline
\end{tabular}

(Sumber : Badan Pusat Statistik Aceh Utara, 2017:11).

Dari tabel 1 diatas dapat dilihat bahwa pada desa Trieng Pantang dilihat dari luas lahan 28 Ha dengan jumlah petani 165 orang. Karena di desa tersebut mata pencaharian pertama adalah bertani dengan menerapkan akad muzara'ah oleh pemilik lahan. Pada desa Trieng Matang Ubi juga demikian dengan luas lahan $33 \mathrm{Ha}$ dengan jumlah petani 193 orang melakukan praktik muzara'ah, karena di desa tersebut luas lahan sawah begitu besar dibandingkan dengan berladang.

Namun pada desa Bintang $\mathrm{Hu}$ luas lahan $44 \mathrm{Ha}$ dengan jumlah petani mencapai 234 dan desa Reudeuep luas lahan $137 \mathrm{Ha}$ dengan jumlah petani yang sangat besar mencapai 418. Pada desa Nga Matang luas lahan 109 Ha dengan jumlah petani 228 juga terdapat petani yang bercocok tanam di sawah yang melakukan praktik muzara'ah.

Salah satu petani yang terdapat pada Desa Tring Pantang sebagai pengelola lahan yang telah dijalankan sejak tahun 2016 hingga sekarang. Pendapatan yang diterima oleh petani sebelum dan sesudah terjadinya akad muzaraah sangat berbeda secara signifikan, hal ini disebabkan karena sebelum adanya akad muzaraah petani hanya menerima pendapatan dari jenis pekerjaan yang ditekuninya saja sementara setelah adanya akad muzaraah pendapatan petani tersebut meningkat yang disebabkan oleh adanya peningkatan dari hasil produksi pertaniannya. Distribusi pendapatan petani sebelum dan sesudah Akad Muzaraah adalah sebagai berikut :
Tabel 2

Jumlah Pendapatan Petani

\begin{tabular}{|c|l|c|}
\hline NO & \multicolumn{1}{|c|}{$\begin{array}{c}\text { Pendapatan } \\
\text { Petani }\end{array}$} & Jumlah \\
\hline 1 & $\begin{array}{l}\text { Sebelum Akad } \\
\text { Muzara'ah }\end{array}$ & Rp. $1.600 .0000,--$ \\
\hline 2 & $\begin{array}{l}\text { Setelah Akad } \\
\text { Muzara'ah }\end{array}$ & \\
\hline
\end{tabular}

Sumber : Hasil penelitian, (2019)

Berdasarkan Tabel 1.2 di atas menunjukkan bahwa Jumlah pendapatan petani sebelum akad muzaraah sebesar Rp. 1.400.000 dan sesudah akad muzaraah meningkat hingga Rp. 1.600.000, dari luas lahan lahan yang di gunakan 1.600 meter.

\section{TINJAUAN TEORITIS}

\section{Muzara'ah}

Dalam menerapkan muzara'ah di kehidupan, perlu diketahui bahwa dalam mendapat ridha dari Allah maka sebagai umat Islam kita diharuskan untuk menjalankan apa yang ada di bumi berdasarkan ketentuan dari hukum yang telah kita ketahui bersama. Maka dalam menjalankan penggarapan lahan perlu adanya pemahamn dari Al-Qur'an dan Hadist.

Berdasarkan Al-Qur'an yang membahas mengenai dasar hukum muzara'ah dapat dilihat sebagai berikut :

Dalam Al-Qur'an pada Surat Al-Muzammil ayat 20 yang berbunyi : “....dan orang-orang yang berjalan di muka bumi mencari sebagian karunia Allah SWT...”. (Q.S. Al-Muzammil, 73:20).

Dari ayat diatas dapat dipahami bahwa ayat tersebut menuntun umat manusia untuk menelusuri jalan Allah. Apabila menjalankan suatu pekerjaan yang maka diharuskan untuk tidak sellu berada di jalan Allah SWT supaya tidak meninggalkan kewajiban yang seharusnya dijalankan.

Pada surat Al-Qur'an lain yang menjadi landasan hukum Muzara'ah yaitu pada surat AlZukhruf ayat 32 yang berbunyi : “Apakah mereka yang membagi-bagi rahmat Tuhanmu? Kami telah menentukan antara mereka penghidupan mereka dalam kehidupan dunia, dan Kami telah 
meninggikan sebahagian mereka atas sebagian yang lain beberapa derajat, agar sebagian mereka dapat mempergunakan sebagian yang lain. Dan rahmat Tuhan-Mu yang lebih baik dari apa yang mereka kumpulkan". (Q.S. Az-Zukhruf, 43:32).

Maksud dari ayat diatas adalah menegaskan bahwa penganugrahan rahmat Allah, apalagi pemberian wahyu, semata-mata adalah wewenang Allah, bukan manusia, apakah mereka yang musyrik, durhaka, dan bodoh itu yang dari saat ke saat dan secara bersinambungan membagibagi rahmat Tuhan pemelihara dan pelimpah rahmat bagimu, wahai nabi yang agung, tidak kami telah membagi melalui penetapa hukumhukum kami tetapkan antara mereka serta berdasar kebijaksanaan kami baik yang bersifat umum maupun khusus.

Maka dapat dipahami bahwa, dalam menjalankan aktivitas di atas bumi sebagai umat Islam yang memiliki sifat toleransi dalam hal tolong menolong. Sudah sangat jelas untuk saling membantu sesama manusia. Karena hal tersebut sudah tercantum dala Al-Qur'an untuk memberikan peluang kepada orang yang lemah dan orang yang lemah dapat menjalankannya dengan kesepakatan suatu pekerjaan.

Sedangkan landasan hukum yang terdapat dalam beberapa Hadist Nabi Muhammad SAW dan juga terdapat dalam beberapa riwayat para sahabat, seperti yang ditulis oleh Imam Muslim (2003:27) salah satunya adalah :"Rasulullah SAW melarang al-muzara'ah". (HR Muslim dari tsabit Ibnu Adhdhahhak).

Dari hadist diatas dapat dipahami, menurut mereka, Boleh saja pertanian itu tidak menghasilkan, sehingga petani tidak mendapatkan apa-apa dari hasil kerjanya. Oleh karena itu unsur spekulasi (untung-untungan) dalam akad ini terlalu besar, obyek akad yang bersifat al-ma'dum dan aljahalah inilah yang membuat akad ini tidak sah.

Adapun dari hadist lain yang menjelaskan muzara'ah tersebut diperbolehkan dengan ketentuan dari hadist dibawah ini yang ditulis oleh Ahmad Zaidun (2006:496) yang berbunyi :

"Rasulullah SAW melakukan akad muzara'ah dengan penduduk Khaibar, Yang hasilnya dibagi antara Rasul dengan para pekerja". (HR al-Bukhari, Muslim, Abu Daud, an-Nasa'I,
Ibnu Majah,at-Tirmizi, dan Imam Ahmad ibn Hanbal dari Abdullah ibn Umar).

Adapun dari hadist diatas dapat diambil kesimpulan bahwa, akad muzara'ah dalam menggarap lahan yang bekerjasama dengan pemilik lahan pada dasarnya todak diperbolehkan. Hal tersebut berdasarkan hadist yang mengatakan tidak boleh karena ada prinsip yang berbeda pada bagi hasilnya. Oleh karena itu, dengan dianjurkan bekerjasama dengan hasil juga dibagi bedua antara pemilik lahan dengan penggarap lahan sama. Dalam arti tidak adanya perbedaan yang merugikan antara kedua belah pihak. Maka kerjasama tersebut saling menolong antara pemilik lahan dengan penggarap tanah, dengan artinya diperbolehkan.

\section{Kesejahteraan Petani}

Pertanian merupakan kegiatan yang memanfaatkan sumber daya yang dilakukan orang untuk memperoleh bahan pangan, bahan baku industri, atau sumber energi, serta untuk mengelola lingkungan. Selain menjadi sumber daya bahan makanan utama, pertanian juga menyumbang potensi lain, baik sebagai bahan perdagangan maupun sebagai bahan dasar industri.

Petani yang sejahterah merupakan masyarakat yang mampu menggunakan sumber pendapatan untuk memenuhi kebutuhan sehari hari. Tingkat kesejahteraan masyarakat bisa diukur dari tingkat pemenuhan kebutuhan keluarga yang meliputi kebutuhan pangan dan non pangan kesejahteraan yang dimaksud adalah terpenuhinya kebutuhan dasar.

\section{METODE PENELITIAN}

\section{Data dan Sumber Data}

Data yang digunakan dalam penelitian adalah data primer yang bersumber dari hasil jawaban dalam kuesioner secara langsung terhadap responden dengan menyertakan pertanyaanpertanyaan dalam kuesioner yang menyangkut dengan pengaruh muzara'ah terhadap tingkat kesejahteraan petani di Kecamatan Lhoksukon Kabupaten Aceh Utara. 


\section{Populasi}

Populasi dalam penelitian ini seluruh masyarakat yang melakukan akad muzara'ah di Kecamatan Lhoksukon yang berada di lima desa dan yang menjadi tempat untuk penelitian ini adalah desa Trieng Pantang, Trieng Matang Ubi, Bintang $\mathrm{Hu}$, Reudeup dan Nga matang Ubi dengan jumlah populasi adalah 67 orang

\section{Sampel}

Teknik pengambilan sampel yang digunakan dalam penelitian ini adalah teknik sensus sampling adalah metode penentuan sampel bila seluruh anggota populasi digunakan sebagai sampel (Jogiyanto, 2005). Sehingga sampel dalam penelitian ini berjumlah 67 pelaku akad muza'raah.

\section{Operasional Variabel}

Penelitian ini menggunakan variabel bebas yaitu Muzara'ah dan variabel terikat adalah kesejahteraan masyarakat.

1. Muzara'ah (X)

Muzara'ah dalam penelitian ini yaitu bagi hasil yang ditetapkan antara penggarap dengan pemilik lahan. Satuan ukuran penghitungnya adalah jumlah bagi hasil yang diukur dalam rupiah.

2. Kesejahteraan Masyarakat (Y)

Kesejahteraan masyarakat dalam penelitian ini merupakan jumlah pendapatan yang diterima oleh petani yang menggunakan akad Muzara'ah. Satuan ukuran adalah rupiah.

\section{Metode Analisis Data}

Analisis data dalam penelitian ini menggunakan analisis regresi linear ederhana. Analisis regresi dengan menggunakan Eviews 8. Persamaan umum regresi linier sederhana yang digunakan dalam penelitian ini yaitu: Adapun formula yang digunakan yaitu :

$$
\mathbf{Y}=\mathbf{a}+\boldsymbol{\beta X}+\mathbf{e}
$$

Dimana :

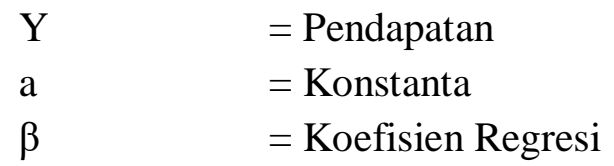$$
=\text { Error term }
$$

\section{Uji Normalitas}

Uji normalitas bertujuan guna menguji apakah di dalam model regresi, variabel residual atau pengganggu terdistribusi normal. Apabila terdapat normalitas, maka residual terdistribusi normal dan independen, yaitu perbedaan antara nilai prediksi dengan skor yang sesungguhnya atau error akan terdistribusi simetri di sekitar nilai means sama juga dengan nol. Untuk uji normalitas data, untuk melihat normalitas residual peneliti melihat dengan Jarque-Bera.

Menurut Mahardika dan Artini (2017) normalitas dapat dideteksi dengan membandingkan nilai Jarque Bera dengan tingkat alpha 0,05, data dapat dikatakan residual berdistribusi normal apabila probalitas $>0,05$.

\section{Uji Asumsi Klasik \\ Uji Multikolinearitas}

Menurut Ghozali dalam Haslinda dan Jamaluddin (2016) uji multikolinieritas dipakai guna mengetahui apakah terdapat korelasi atau hubungan diantara variabel independen. Multikolinieritas menyatakan hubungan atau korelasi antar sesama variabel independen. Model regresi yang baik seharusnya tidak terdapat kolerasi antar variabel independen. Menurut Iqbal (2015) multikolinearitas dapat dideteksi dengan melihat nilai dari centered VIF dengan pengujian variance inflation factor, jika nilai VIF (Variance Inflation Factor) tidak lebih dari 10, maka model tersebut dapat dikatakan bebas dari multikolinieritas.

\section{Uji Heteroskedastisitas}

Uji heteroskedastisitas bertujuan untuk menguji apakah dalam model regresi terjadi ketidaksamaan variance dari residual satu pengamatan ke pengamatan lain. Menurut (Widarjono, 2013) Keputusan terjadi atau tidaknya heteroskedastisitas pada model regresi linier dapat dilihat melalui chi Square hitung $\left(\mathrm{X}^{2}\right)$ lebih kecil dari chi squared $\left(X^{2}\right)$ tabel pada tingkat $\alpha=5 \%$. 


\section{Pengujian Hipotesis}

\section{Pengujian Parsial (Uji t)}

Kriteria penilaian dengan metode ini adalah jika nilai dari $t_{\text {hitung }}$ lebih besar dari $t_{\text {tabel}}$, maka hipotesis penelitian diterima, dan sebaliknya. Menurut Ghozali dalam Galatang et all (2016) uji statistik t dasarnya menunjukkan seberapa jauh pengaruh satu variabel bebas secara individu dalam menerangkan atau menjelaskan variabel terikat. Pengujian ini dilakukan dengan memakai signifikan level 0,05 ( $\alpha=5 \%)$.

Penerimaan atau penolakan sebuah hipotesis dilakukan dengan kriteria : Apabila nilai signifikan > 0,05 maka hipotesis ditolak. Ini berarti secara parsial variabel bebas tidak memiliki pengaruh secara signifikan terhadap variabel terikat. Apabila nilai signifikan $\leq 0,05$ maka hipotesis diterima. Ini berarti secara parsial variabel bebas tersebut memiliki pengaruh yang signifikan terhadap variabel terikat.

\section{Pengujian Simultan (Uji F)}

Menurut Ghozali dalam Galatang et all (2016) uji statistik F dasarnya menunjukkan apakah semua variabel bebas yang dipakai dalam model memiliki pengaruh secara bersama-sama terhadap variabel terikat. Metode penelitian secara simultan yang dipakai dalam penelitian ini adalah menggunakan nilai $\operatorname{Sig}<\alpha$, atau bisa dengan $F_{\text {hitung }}$ dibandingkan dengan nilai $F_{\text {tabel }}$. Kriteria penilaian Uji $\mathrm{F}$ adalah jika nilai $\mathrm{F}_{\text {hitung }}$ lebih besar dari $\mathrm{F}_{\text {tabel }} ; \mathrm{F}_{\text {hitung }}>\mathrm{F}_{\text {tabel }}$ maka hipotesis penelitian diterima, dan sebaliknya. Uji statistik F : Taraf signifikan $\alpha=0,05$. Hal ini berarti secara simultan variabel-variabel independen atau bebas memiliki pengaruh signifikan terhadap variabel terikat dan begitu juga sebaliknya.

\section{Koefisien Korelasi dan Koefisien Determinasi}

Menurut Sugiyono dalam Akila (2017) analisis koefisien korelasi dipakai guna membandingkan hasil pengukuran dua variabel berbeda agar bisa menentukan hasil hubungan antara variabel. Menurut Arbayah (2013) koefisien korelasi digunakan untuk mengetahui kuatnya hubungan antara variabel tidak bebas dengan variabel bebas. Semakin besar dari nilai $\mathrm{R}$, maka akan semakin tepat model regresi yang digunakan sebagai alat permainan karena total variasi bisa menjelaskan variabel tidak bebas.

Menurut Ghozali dalam Jayantara dan Dharmadiaksa (2016) koefisien determinasi $\left(\mathrm{R}^{2}\right)$ intinya mengukur seberapa jauh kemampuan model regresi dalam menerangkan atau menjelaskan variasi variabel dependen. Nilai koefisien determinasi yaitu antara 0 (nol) dan 1 (satu). Nilai $\mathrm{R}^{2}$ yang kecil artinya kemampuan variabel-variabel bebas dalam menjelaskan atau menerangkan variasi variabel terikat sangat terbatas. Nilai yang mendekati satu artinya variabel-variabel bebas memberikan hampir seluruh informasi yang dibutuhkan guna memprediksi variasi variabel terikat.

\section{HASIL PENELITIAN DAN PEMBAHASAN}

\section{Gambaran Umum Lokasi Penelitian}

Kabupaten Aceh Utara merupakan bagian dari Provinsi Aceh yang berada di sebelah utara. Berdasarkan Peta Bakosurtanal skala 1 : 50.000, maka secara geografis Kabupaten Aceh Utara terletak pada posisi 960 47' - 970 31' Bujur Timur dan 040 43' - 050 16' Lintang Utara. Batas wilayah Kabupaten Aceh Utara dengan wilayah lainnya sebagaimana pada Gambar 2.1 adalah:

- Sebelah utara : Kota Lhokseumawe dan Selat Malaka.

- Sebelah timur : Kabupaten Aceh Timur.

- Sebelah selatan : Kabupaten Bener Meriah.

- Sebelah barat : Kabupaten Bireuen.

Luas wilayah Kabupaten Aceh Utara yang tercatat adalah 3.296,86 km2, atau $329.686 \mathrm{Ha}$. Dengan panjang garis pantai $51 \mathrm{~km}$, dan kewenangan kabupaten adalah sampai 4 mil laut, maka luas wilayah laut kewenangan ini adalah $37.744 \mathrm{Ha}$ atau $3.774,4 \mathrm{~km} 2$

Salah satu kecamatan yang mempunyai banyak Petani yaitu Kecamatan Lhoksukon. Penelitian dilakukan pada 5 desa yaitu Trieng Pantang, Trieng matang Ubi, Bintang Hu, Reudeup dan Nga Matang Ubi di Kecamatan Lhoksukon Kabupaten Aceh Utara 


\section{Uji Normalitas}

Uji normalitas diperlukan untuk mengetahui distribusi data, apakah berdistribusi normal atau tidak.Pada penelitian ini uji normalitas yang dilakukan menggunakan tabel HistogramNormality Test.

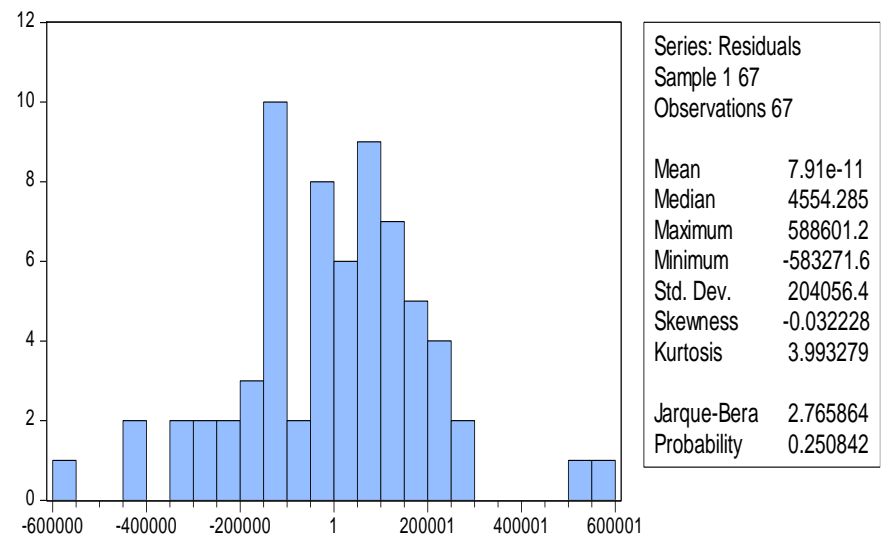

Sumber : Hasil Penelitian (Data Diolah:2018)

\section{Gambar 1}

\section{Hasil Uji Normalitas}

Nilai JB hitung sebesar $0,250>0,05$ sehingga dapat disimpulkan bahwa residual terdistribusi normal yang artinya asumsi klasik tentang kenormalan telah dipenuhi.

\section{Uji Asumsi Klasik}

\section{Uji Heteroskedastisitas}

Heteroskedastisitas terjadi pada saat residual dan nilai prediksi memiliki korelasi atau pola hubungan. Untuk mendeteksi ada tidaknya heteroskedastisita maka dengan membandingkan nilai R-squared dan tabel $\mathrm{X}^{2}$.

a. Jika nilai Obs*R-squared $>X^{2}$ (chi-square) tabel, maka tidak lolos dari uji heteroskedastisitas.

b. Jika nilai Obs*R-squared $<\mathrm{X}^{2}$ (chi-square) tabel, maka lolos dari uji heteroskedastisitas

\section{Tabel 3}

\section{Hasil Uji Heteroskedastisitas}

\begin{tabular}{|l|r|l|c|}
\hline \multicolumn{4}{|c|}{ Heteroskedasticity Test: Breusch-Pagan-Godfrey } \\
\hline F-statistic & 2.394435 & Prob. F(3,72) & 2.394435 \\
\hline $\begin{array}{l}\text { Obs*R- } \\
\text { squared }\end{array}$ & 4.664335 & $\begin{array}{l}\text { Prob. Chi- } \\
\text { Square(3) }\end{array}$ & 4.664335 \\
\hline $\begin{array}{l}\text { Scaled } \\
\text { explained } \\
\text { SS }\end{array}$ & 7.939559 & $\begin{array}{l}\text { Prob. Chi- } \\
\text { Square(3) }\end{array}$ & 7.939559 \\
\hline
\end{tabular}

Sumber : Hasil Penelitian (Data Diolah:2018)
Dari hasi tabel 3 di atas dapat dilihat bahwa nilai obs* R-square untuk hasil estimasi uji Glejser adalah sebesar 4,664 dan nilai $\mathrm{X}^{2}$ tabel dengan derajat kepercayaan 5\% dan df adalah 84,82 karena nilai Obs*R-squared $(4,66)<\mathrm{X}^{2}$ (chi-square) tabel $(84,82)$ maka dapat disimpulkan bahwa model diatas lolos dari heteroskedastisitas.

\section{Analisis Regresi Linier sederhana}

Untuk mengetahui hasil penelitian dilihat dari output regresi linier berganda menggunakan Eviews sebagai alat analisis. Berikut hasilnya pada tabel 4 :

\section{Tabel 4}

\section{Hasil Regresi Muzara'ah Terhadap Tingkat Kesejahteraan Petani DiKecamatan}

\section{Lhokseumawe Kabupaten Aceh Utara}

\begin{tabular}{|lrlrr|}
\hline \multicolumn{1}{|c}{ Variable } & Coefficient & Std. Error & t-Statistic & \multicolumn{1}{c|}{ Prob. } \\
\multicolumn{1}{c}{ C } & 550399.5 & 110855.9 & 4.964999 & 0.0000 \\
\multicolumn{1}{c}{ Muzara'ah } & 0.927118 & 0.074479 & 12.44810 & 0.0000 \\
R-squared & 0.704485 & Mean dependent var & 1886418. \\
Adjusted R- & & & \\
squared & 0.699939 & S.D. dependent var & 414629.1 \\
S.E. of & 227124.8 & Akaike info criterion & 27.53378 \\
regression & $3.35 E+12$ & Schwarz criterion & 27.59959 \\
Sum squared & -920.3817 & Hannan-Quinn criter. & 27.55982 \\
resid & 154.9553 & Durbin-Watson stat & 1.942772 \\
Log likelihood & 0.000000 & & \\
F-statistic & & & \\
Prob(F-statistic) & & & \\
\hline
\end{tabular}

Sumber : Hasil Penelitian (Data Diolah:2018)

Dari tabel 4 di atas maka model regresi linier sederhana adalah sebagai berikut : $\mathrm{Y}=550399,5+0,927118 \mathrm{X}$

Dari hasil diatas dapat di interpretasi hasil analisis regresi linier sederhana yaitu sebagai berikut :

- Constanta sebesar 550399,5 menunjukkan apabila variabel muzara'ah bernilai nol maka variabel dependen kesejahteraan petani mempunyai nilai sebesar Rp 550399,5.

- Koefisien variabel muzara'ah mempunyai nilai sebesar Rp. 0,927118, Hal ini menunjukkan hubungan yang positif. Artinya apabila muzara'ah mengalami peningkatan Rp.1 maka kesejahteraan petani akan mengalami peningkatan sebesar Rp. 0,927118. 


\section{Hasil Uji Parsial (t)}

Uji hipotesis yang dipakai dalam penelitian ini terdiri dari pengujian secara parsial dan pengujian secara simultan. Suatu variabel dinyatakan berpengaruh secara parsial apabila nilai $\mathrm{t}$ hitung lebih besar dari $\mathrm{t}$ tabel para taraf signifikan $5 \%$ atau lebih kecil dari 0,05 . Adapun nilai untuk $t$ tabel di peroleh melalui perhitungan rumus N-k-1 yaitu $67-1-1=65$ pada taraf signifikan $5 \%$ maka di temukan nilai $\mathrm{t}$ tabel sebesar 1,668. Berdasarkan Tabel 5 di atas maka dapat di jelaskan hasil pengujian hipotesis sebagai berikut :

Secara Parsial muzara'ah berpengaruh positif dan signifikan terhadap kesejahteraan petani di Kecamatan Lhoksukon Kabupaten Aceh Utara yang di buktikan dengan hasil uji statistik $\mathrm{t}$ hitung $>\mathrm{t}$ tabel $(12,448>1,668)$ dan tingkat signifikansinya lebih kecil dari 0,05 yaitu 0,000 . ( $\mathrm{H}_{1}$ diterima).

\section{Koefisien Determinasi $\left(\mathbf{R}^{\mathbf{2}}\right)$}

Berdasarkan Tabel 5 diatas hasil uji Koefisen determinasi $\mathrm{R}^{2}$ sebesar 0,704 atau 70,4\%. Hasil ini berarti muzara'ah mampu mempengaruhi kesejahteraan petani sebesar 70,4 \% Sedangkan sisanya $29,6 \%$ di pengaruhi oleh faktor-faktor lain yang tidak masuk dalam penelitian ini seperti luas lahan dan jumlah produksi. Kesejahteraan petani dalam hal ini juga dipengaruhi oleh faktor lain seperti adanya pekerjaan lain selain bertani seperti berjualan dan peternakan. Kesejahteraan masyarakat dapat dilihat dari besarnya pendapatan yang di hasilkan, dengan adanya tambahan pendapatan yang di terima oleh petani tersebut dari hasil jualan maka akan meningkatkan tingkat kesejahteraannya.

\section{Koefisien Korelasi (R)}

Koefisien Korelasi (R) adalah untuk melihat pengaruh variabel independen terhadap variabel dependen berpengaruh kuat secara positif atau berpengaruh kuat secara negatif. $\mathrm{R}$ terletak antara $(-1<\mathrm{R}<1)$. Hasil yang diperoleh berdasarkan Tabel 4.3 untuk koefisien determinasi $\left(\mathrm{R}^{2}\right)$ adalah sebesar 0,704, maka koefisien korelasi (R) adalah sebesar $\sqrt{R^{2}}=\sqrt{0,704}=0,8390$. Hasil ini berhubungan kuat secara positif, karena nilai $\mathrm{R}$ mendekati positif $(+1)$.

\section{Pembahasan}

\section{Pengaruh Muzara'ah Terhadap Tingkat} Kesejahteraan Petani Di Kecamatan

\section{Lhoksukon Kabupaten Aceh Utara}

Hasil Penelitian menunjukkan bahwa muzara'ah berpengaruh positif dan signifikan terhadap kesejahteraan petani di Kecamatan Lhoksukon Kabupaten Aceh Utara yang di buktikan dengan hasil uji statistik $\mathrm{t}$ hitung $>\mathrm{t}$ tabel ( $12,448>1,668)$ dan tingkat signifikansinya lebih kecil dari 0,05 yaitu 0,000. ( $\mathrm{H}_{1}$ diterima). Muzara'ah adalah suatu cara untuk menjadikan tanah pertanian menjadi produktif dengan bekerja sama antara pemilik tanah dengan penggarap dalam memproduktifkannya, dan hasilnya dibagi antara mereka berdua dengan perbandingan yang dinyatakan dalam perjanjian atau berdasarkan adat kebiasaan.

Diterapkannya bagi hasil sistem muzara'ah berdampak pada sektor pertumbuhan sosial ekonomi adanya rasa saling tolong-menolong atau saling membutuhkan antara pihak-pihak yang bekerjasama. Sesuai dengan firman Allah SWT didalam surat al-Maidah ayat 2 yang berbunyi:"Dan tolong-menolonglah kamu dalam mengerjakan kebajikan dan takwa, dan jangan tolong-menolong dalam berbuat dosa dan permusuhan., Meningkatnya penghasilan ekonomi pertanian baik penggarap maupun pemilik lahan, dapat mengurangi pengangguran, meningkatkan produksi pertanian dalam negeri. dapat mendorong pengembangan sektor riil yang menopang pertumbuhan ekonomi secara makro.

Praktek muzara'ah ini sangatlah cocok dan memberikan solusi terhadap masyarakat pedesaan yang mayoritas mata pencahariannya mengandalkan dari hasil pertanian. Pertanian memiliki peran penting dalam transformasi ekonomi pedesaan. Sektor pertanian juga akan mempengaruhi aktivitas nonpertanian di pedesaan melalui tiga cara, yaitu produksi, konsumsi, dan keterkaitan pasar tenaga kerja. Pada sisi produksi, pertumbuhan sektor pertanian memerlukan input berupa pupuk, pestisida, benih. Pada sisi konsumsi, meningkatnya pendapatan menyebabkan konsumsi rumah tangga tani meningkat, yang juga berarti permintaan barang ataupun jasa yang dihasilkan sektor nonpertanian meningkat. Jenis dan jumlah 
produk yang dihasilkan sektor pertanian di suatu daerah juga mempengaruhi aktivitas-aktivitas nonpertanian yang akan berkembang (pemasaran, pengolahan, ataupun transportasi).

.Hasil penelitian Zainuddin $\mathrm{S}$ dan Eno (2015) menyimpulkan bahwa terdapat pengaruh yang signifikan pada penerapan sistem bagi hasil muzara'ah terhadap kesejahteraan masyarakat agraris di Kabupaten Luwu Timur.

\section{KESIMPULAN DAN SARAN}

\section{Kesimpulan}

Berdasarkan hasil penelitian dan pembahasan, maka peneliti mengemukakan kesimpulan sebagai berikut :

1. Secara Parsial muzara'ah berpengaruh positif dan signifikan terhadap kesejahteraan petani di Kecamatan Lhoksukon Kabupaten Aceh Utara yang di buktikan dengan hasil uji statistik $\mathrm{t}$ hitung $>\mathrm{t}$ tabel $(12,448>1,668)$ dan tingkat signifikansinya lebih kecil dari 0,05 yaitu 0,000. ( $\mathrm{H}_{1}$ diterima). Muzara'ah adalah suatu cara untuk menjadikan tanah pertanian menjadi produktif dengan bekerja sama antara pemilik tanah dengan penggarap dalam memproduktifkannya, dan hasilnya dibagi antara mereka berdua dengan perbandingan yang dinyatakan dalam perjanjian atau berdasarkan adat kebiasaan.

2. Koefisen determinasi $\mathrm{R}^{2}$ sebesar 0,704 atau 70,4\%. Hasil ini berarti muzara'ah mampu mempengaruhi kesejahteraan petani sebesar $70,4 \%$ Sedangkan sisanya 29,6\% di pengaruhi oleh faktor-faktor lain yang tidak masuk dalam penelitian ini seperti luas lahan dan jumlah produksi.

3. Hasil koefisien korelasi $(\mathrm{R})$ adalah sebesar $\sqrt{R^{2}}$ $=\sqrt{0,704}=0,8390$. Hasil ini berhubungan kuat secara positif, karena nilai $\mathrm{R}$ mendekati positif $(+1)$

\section{Saran}

Pada penelitian yang akan datang terdapat beberapa hal yang perlu diperhatikan, diantara adalah sebagai berikut:
1. Diharapkan bagi peneliti selanjutnya dengan memperluas lokasi penelitian sehingga dapat memperoleh hasil yang lebih signifikan.

2. Di harapkan bagi peneliti selanjutnya, hendaknya menambahkan variabel lain yang mempengaruhi pendapatan petani.

3. Diharapkan bagi petani, untuk melakukan kegiatan atau jenis pekerjaan lain yang dapat menambah jumlah pendapatannya setiap bulan sehingga akan meningkatkan kesejahteraan hidupnya.

4. Diharapkan bagi Pengelola lahan, Untuk dapat mengelola lahan dengan sebaik mungkin sehingga akan memperoleh hasil produksi yang lebih banyak.

5. Bagi pemilik lahan, diharapkan melakukan akad muzaraah dengan petani petani yang secara umum tidak memiliki lahan sendiri sehingga dapat membantu mensejahterakan kehidupan masyarakat miskin.

\section{DAFTAR PUSTAKA}

As-Shididieqy, Tengku Muhammad Hasbi. (1998). Pengantar Fiqh Mu'amalah, Bulan Bintang. Jakarta

Hasan, M. Ali (2013). Berbagai Macam Transaksi dalam Islam. Raja Grafindo. Jakarta

Lubis, Suhwardi K. Hukum Ekonomi Islam. Sinar Grafika. Jakarta

Mas'adi, Ghufron A (2002). Fiqh Mu'amalah kontekstual. Raja Grafindo Persada, Jakarta

Mardani, (2012). Fiqh Ekonomi Syari'ah, Kencana Prenada Media Group. Jakarta.

Muslim, Imam (2003). Shahih Muslim, Dar alFirk. Liban

Muslich, Ahmad Wardi. (2010). Fiqh Muamalah. Mizan. Jakarta Syafe'i,

Qordhawi, Syekh Muhammad Yusuf. (1993). Halal dan Haram Dalam Islam. Bina Ilmu Jakarta

Qardawi, Syekh Muhammad Yusuf (2001). Halal Dan Haram Dalam Islam. Bina Ilmu. Jakarta

Rachmat (2001). Fiqh Muamalah. Pustaka Setia. Bandung

Syafe'i, Rachmad (2001). Fiqih Mu'amalah. Bandung. Pustaka setia.

Sabiq, Sayyid. (2009). Fikih Sunnah. Pena Pundi Aksara. Jakarta 
Zaidun, Ahmad (2006). Ringkasan Hadist Shahih Al-Bukhari, Pustaka Amani. Jakarta

Zuhdi, Masyfuk. (1997). Masail Fiqhiyah (Kapita Selekta Hukum Islam), Toko Gunung Agung. Jakarta

Zuhaily, Wahbah. (2005). Al-Fiqhu al-islami wa Adilatuh. Dar al-Fikr. Beiru Libanon

Zuhdi, Masyfuk, Masail Fiqhiyah. (1996). Kapita selekta hukum Islam. Raja Grafindo Persada. Jakarta 